УДК 657

\title{
ФОРМУВАННЯ МАРКЕТИНГОВОЇ ПОЛІТИКИ ПІДПРИЕМСТВА ЯК ОСНОВА ВДОСКОНАЛЕННЯ СИСТЕМИ ЗБУТУ
}

\section{FORMATION OF MARKETING POLICY OF THE ENTERPRISE AS A BASIS FOR IMPROVING THE SALES SYSTEM}

\author{
Гуріна Наталія Валеріївна \\ кандидат економічних наук, доцент, \\ Університет державної фріскальної служби України \\ ORCID: https://orcid.org/0000-0001-9433-069X \\ Бестюк Анастасія Миколаївна \\ студентка, \\ Університет державної фріскальної служби України \\ ORCID: https://orcid.org/0000-0002-7776-5496 \\ Gurina Nataliya, Bestiuk Anastasia \\ University of the State Fiscal Service of Ukraine
}

\begin{abstract}
У статті розглянуто важливість системи збуту в умовах перенасиченості ринку. Визначено основні завдання збутової діяльності. Описано збутовий процес в господарській діяльності підприємства. Досліджено фрактори впливу на збутову стратегію. Проаналізовано етапи фрормування маркетингової збутової політики. Досліджено методи для співпраці між посередниками в процесі збутової діяльності. Описано важливість засобів стимулювання збуту. Визначено цільові групи та види стимулювання. Визначено стратегічні заходи, спрямовані на оптимізацію витрат на управління збутом. Обґрунтовано важливість пошуку оптимального рівня обслуговування. Розглянуто обґрунтування всіх витрат, що пов'язані із дослідженням ринку, рекламою та стимулюванням збуту з метою забезпечення високого конкурентного статусу підприємства. Надано рекомендації для стимулювання збуту.
\end{abstract}

Ключові слова: збут, оптимізація збутових витрат, маркетинг, маркетингова політика, маркетингові інструменти.

В статье рассмотрены важность системы сбыта в условиях перенасыщенности рынка. Определены основные задачи сбытовой деятельности. Описаны сбытовой процесс в хозяйственной деятельности предприятия. Исследованы факторы влияния на сбытовую стратегию. Проанализированы этапы фрормирования маркетинговой сбытовой политики. Исследованы методы для сотрудничества между посредниками в процессе сбытовой деятельности. Описаны важность средств стимулирования сбыта. Определены целевые группы и виды стимулирования. Определены стратегические меры, направленные на оптимизацию расходов на управление сбытом. Обоснованно важность поиска оптимального уровня обслуживания. Рассмотрены обоснование всех затрат, связанных с исследованием рынка, рекламой и стимулированием сбыта с целью обеспечения высокого конкурентного статуса предприятия. Даны рекомендации для стимулирования сбыта.

Ключевые слова: сбыт, оптимизация сбытовых расходов, маркетинг, маркетинговая политика, маркетинговые инструменты.

The article considers the importance of the sales system in conditions of market saturation. The main tasks of sales activity are determined. Sales activities are all of the actions, sales practices, and strategies that sales reps and managers do daily to move prospects and customers through the sales process. All of these activities directly lead to deals being closed and sales goals being met. Once you get into sales activity management and you are tracking activities, these broad categories of activities can be broken down even further to gain more insight. For example, visits/meetings can be broken down to determine the number of visits that were first-time sales meetings with a prospect, or product demo meetings, or follow up visits with existing customers. There are also some things that sales reps spend their time on each day that would be considered sales activities, but they can only be measured by their result. One example would be prospecting. The effectiveness of a sales rep's prospecting efforts is evident in 
the number of new leads that they are adding to the sales funnel. So, the leads themselves are not the sales activity, the prospecting is. The outcome of sales activities also allows an opportunity to look at ways to streamline each activity as well as the consequent activities related to it. For sales managers, sales activities, from a broad perspective, provide insight into how the sales team as a whole is doing, provide an overall picture of sales performance, offer a way to motivate the competitiveness of reps, and give insight into customer satisfaction. It is important to understand that you have direct control over input from sales activities. The more you improve sales activities the more you will improve sales effectiveness. The sales process in the economic activity of the enterprise is described. Factors influencing the sales strategy are investigated. The stages of formation of marketing sales policy are analyzed. Methods for cooperation between intermediaries in the process of sales activities are studied. The importance of sales promotion tools is described. Target groups and types of incentives are identified. Strategic measures aimed at optimizing sales management costs are identified. The importance of finding the optimal level of service is substantiated. The justification of all costs related to market research, advertising and sales promotion in order to ensure a high competitive status of the enterprise is considered. Recommendations for sales promotion are given.

Keywords: sales, sales cost optimization, marketing, marketing policy, marketing tools.

Постановка проблеми. В період розвитку глобалізаційних процесів, що характеризуються перенасиченістю ринку, важливого значення набуває ефективна збутова політика підприємства. Маркетингова політика є важливою передумовою безперебійного функціонування підприємства в сорері збутової діяльності. А збут в свою чергу є однією з найважливіших фрункцій в процесі господарської діяльності суб'єктів господарювання. 3 метою вдосконалення системи збуту та забезпечення конкурентоспроможності підприємства доцільно застосовувати інструменти маркетингової політики такі як: система заохочень та оптимізація транспортних витрат.

Аналіз останніх досліджень і публікацій. Дослідженням формування маркетингової політики підприємства займались такі вчені як: Л.В. Балабанова, І.Г. Клімова, Ф. Котлер, В.П. Мусаткіна, Ю.В. Огерчук та ін. Однак колосальні наукові праці, присвячені проблемам формування маркетингової політики як основа вдосконалення системи збуту, вказують на те, що дана проблема все ще є недостатньо вивченою як в теоретичному, так і в практичному аспектах.

Виділення невирішених раніше частин загальної проблеми. Слід відзначити, що виникає необхідність у поглибленні теоретичних досліджень і вивченні фракторів, пов'язаних із фрормуванням маркетингової системи комунікацій як складової ринкового механізму управління маркетинговою діяльністю підприємства.

Формулювання цілей статті. Метою дослідження $€$ виявлення чинників впливу на фрормування маркетингової політики та інструменти ії̈ вдосконалення.

Виклад основного матеріалу дослідження. Збутову політику підприємства трактують як цілеспрямовану діяльність, здійснення якої полягає в організації руху потоку товарів до кінцевого споживача. Збут продукції є найважливішим елементом маркетингової діяльності підприємства, тому що саме на цьому етапі виготовлена продукція потрапляє на ринок і реалізується, а підприємство одержує прибутки.

Для забезпечення ефективної реалізації вироблених товарів підприємство застосовує комплекс заходів, які забезпечують розподіл товарної ваги в ринковому просторі, доведення товарів до споживачів та організацію їх ефрективного споживання (експлуатації). Це відображається в розробленні маркетингової збутової стратегії (рис. 1).

Під час формування збутової стратегії враховуються фрактори впливу:

- особливість кінцевих споживачів (кількість, рівень доходів);

- можливості підприємства (фрінансовий стан, конкурентоспроможність, масштаби виробництва);

- характеристики товару (вигляд, ціна, сезонність виробництва, терміни зберігання);

- ступінь конкуренції та збутова політика конкурентів;

- особливості збуту (звичаї та торгова практика, щільність розподілу покупців);

- порівняльна вартість різних збутових систем.

Зміни збутової політики зумовлюють істотні структурні перебудови у системі налагодженого каналу збуту, такі зміни повинні відповідати наступним етапам фрормування маркетингової збутової політики:

1) визначення цілей збуту;

2) вибір стратегії збуту;

3) вибір цільової аудиторії;

4) пошук шляхів здійснення співпраці між учасниками кожного каналу розподілу;

5) розробка технології контролю збутової діяльності загалом, за кожному каналу розподілу та окремими посередниками [1]. 


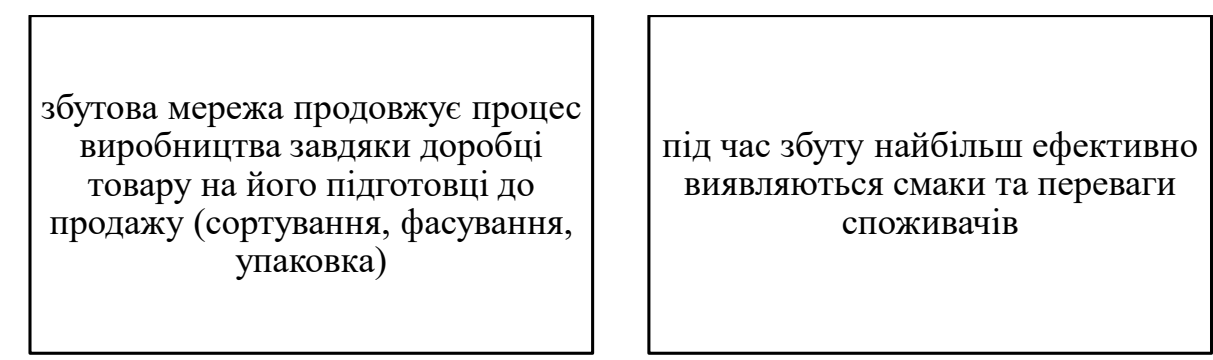

виробник є більш конкурентноспроможним

Рис. 1. Роль збуту в маркетинговій діяльності

Джерело: [1]

Можливість співпраці базується на зі спільності інтересів з реалізації конкретного товару. Однак для того, щоб вона могла бути реалізована з максимальним прибутком для всіх сторін, застосовують методи, стимулюючі співпрацю:

- мотивування ділянок (вдосконалювати конкурентоспроможність товару)

- фрормалізація відносин (забезпечення регулярних контактів з посередником);

- програмування майбутньої діяльності (створення сприятливих умов для співпраці в майбутньому).

Дані показники, як правило, використовуються під час оцінювання ефективної діяльності посередників та каналів збуту. Отримані значення показників аналізуються, а результати $€$ підставою для прийняття рішень щодо можливої співпраці або ж відмови від неї.

Від правильного визначення цільової аудиторії залежить як вибір стратегії, так і ефрективність комплексу комунікацій (табл. 1).

Для вдосконалення збутової діяльності приймають стратегічні заходи, спрямовані на оптимізацію витрат на управління збутом та пошук оптимального рівня обслуговування.

Керівники мають зосереджуватись дії на питаннях виконання та впровадження передових прийомів та методів організації праці, які передбачають диференціацію заробітної плати за результатами діяльності та застосування комплексного механізму мотивування через посилення зацікавленості працівників (подарунки, проведення змагань, комісійні винагороди). Доцільно систематично прово- дити аналіз коштів, необхідних для вжиття цих заходів, та аналіз економічних результатів діяльності [3].

Аналіз витрат варто проводити регулярно для постійного контролю витрат і збитків, що дасть змогу виявити необґрунтовані втрати та недоцільне використання коштів на маркетингові операції. Формувати бюджет на позавиробничі витрати підприємства, пов'язані 3 проведенням маркетингових досліджень та рекламуванням власної продукції, необхідно за допомогою аналітичних методів маркетингу, орієнтуючись на ринкову кон'юнктуру (оптимальне значення суми маркетингових витрат прямуватиме до максимуму).

Оптимізація транспортних витрат на перевезення товару сприятиме скороченню витрат на одиницю товару під час постачання товарів споживачам. У цьому разі варто розглядати витрати, що утворюються під час розподілу товару через прямий канал збуту та опосередкований [4].

Комплексний підхід до визначення оптимального рівня обслуговування для підприємств передбачає збільшення витрат через:

- дотримання зазначених договором термінів постачання товару;

- встановлення комплексу знижок з ціни;

- усунення втрат від пошкодження тари;

- зберігання товару на складах;

- гарантійне обслуговування та заміну.

Отже, маркетингова політика $є$ важливою частиною в системі стимулювання збуту, що включає в себе роботу з товаром, цінову політику та канали розподілу товарів. 
Таблиця 1

Засоби стимулювання основних цільових груп

\begin{tabular}{|c|c|c|}
\hline $\begin{array}{c}\text { Цільова } \\
\text { група }\end{array}$ & Вид стимулювання & Переваги \\
\hline Споживач & $\begin{array}{l}\text { Преміальні упаковки; безкоштовні поштові } \\
\text { відправлення; участь у безкоштовних } \\
\text { жеребкуваннях, лотереї (роздачі); } \\
\text { запрошення по телесрону; призи, купони } \\
\text { або пропозиції за пільговою ціною; } \\
\text { пропозиції про повернення грошей; схеми } \\
\text { надання товару на пробу; прямі поштові } \\
\text { відправлення; безкоштовні подарунки; } \\
\text { торговельні купони; спонсорське } \\
\text { стимулювання; благодійне стимулювання }\end{array}$ & $\begin{array}{l}\text { Стимулюють активність } \\
\text { споживачів. } \\
\text { Створюють контингент } \\
\text { постійних покупців. Підвищують } \\
\text { престиж товарної марки. } \\
\text { Стимулює початкові і повторні } \\
\text { закупки. } \\
\text { Високий рівень привертання уваги. } \\
\text { Особистий контакт, } \\
\text { селективність, високий рівень } \\
\text { сприйняття споживачами. } \\
\end{array}$ \\
\hline $\begin{array}{l}\text { Споживач/ } \\
\text { торгівля }\end{array}$ & $\begin{array}{l}\text { Схеми з багатьма товарними марками; } \\
\text { купони або пропозиції за пільговою } \\
\text { ціною; комплекти за зниженою вартістю; } \\
\text { конкурси; персональне стимулювання; } \\
\text { стимулювання, розраховане на } \\
\text { конкретного споживача; засоби } \\
\text { стимулювання, які проводять у магазині; } \\
\text { упакування-комплекти; виставки. }\end{array}$ & $\begin{array}{l}\text { Високий рівень стимулювання, } \\
\text { ефективний засіб збільшення } \\
\text { обсягів збуту. }\end{array}$ \\
\hline Торгівля & $\begin{array}{l}\text { Наради; ділові подарунки; премії дилерові } \\
\text { за закупівлю; заохочення дилера; } \\
\text { торговельні бонуси; залучення рекламних } \\
\text { коштів; активне рекламування товару } \\
\text { в магазині; заходи заохочення. } \\
\end{array}$ & $\begin{array}{l}\text { Високий рівень привертання } \\
\text { уваги. } \\
\text { Наочність. }\end{array}$ \\
\hline $\begin{array}{l}\text { Працівники } \\
\text { служби збуту }\end{array}$ & $\begin{array}{l}\text { Схеми заохочень; наради; заохочувальні } \\
\text { поїздки. }\end{array}$ & $\begin{array}{l}\text { Підвищують кваліфікацію } \\
\text { торговельних працівників. }\end{array}$ \\
\hline
\end{tabular}

Джерело: сорормовано автором на основі [2]

Висновки. При дослідженні фоормування маркетингової політики необхідно зазначити, що вона $\epsilon$ чинником забезпечення конкурентоспроможності підприємств. Збутова політика підприємства характеризується широким застосуванням різноманітних комунікаційних засобів і появою нових інстру- ментів інформаційного впливу. Комплексний підхід 3 використанням інструментів маркетингової політики вдосконалює систему збуту. Найбільш вагомими інструментами є системи заохочень, які стимулюють збільшення обсягів збуту та оптимізація транспортних витрат.

\section{СПИСОК ВИКОРИСТАНИХ ДЖЕРЕЛ:}

1. Балабанова Л.В., Холод В.В., Балабанова І.В. Маркетинг підприємства : навч. посіб. Київ : Центр учбової літератури, 2012. 612 с.

2. Балабанова Л.В., Сардак О.В. Діагностика конкурентоспроможності бренду підприємства-роботодавця. Економічний часопис-XXI. 2014. № 1-2(1). C. 94-97. URL: http://nbuv.gov.ua/UJRN/ecchado_2014_1-3(1)_25 (дата звернення: 07.10.2021).

3. Ільченко Т.В. Актуальні аспекти формування ефрективної маркетингової комунікаційної політики підприємства. Науковий вісник Ужгородського національного університету. Міжнародні економічні відносини та світове господарство. 2018. № 18. С. 29-33. URL: http://www.visnyk-econom.uzhnu.uz.ua/archive/ 18_2_2018ua/8.pdf (дата звернення: 07.10.2021).

4. Юрченко А.І. Економічна сутність та склад витрат на збут. Розвиток системи обліку, аналізу та аудиту в Україні: теорія, методологія, організація : зб. тез. доп. учасників XVIII всеукр. наук. конф., м. Київ, 2020. С. 97-100.

\section{REFERENCES:}

1. Balabanova L.V., Kholod V.V., Balabanova I.V. (2012) Marketynh pidpryiemstva [Enterprise marketing]. Kyiv: Tsentr uchbovoi literatury. (in Ukrainian) 
2. Balabanova L.V., Sardak O.V. (2014) Diahnostyka konkurentospromozhnosti brendu pidpryiemstva-robotodavtsia [Diagnosis of the competitiveness of the brand of thr employer]. Economic Journal-XXI (electronic journal), vol. 1-2(1). Retrieved from: http://nbuv.gov.ua/UJRN/ecchado_2014_1-3(1)_25

3. Ilchenko T.V. (2018) Aktualni aspekty formuvannia efektyvnoi marketynhovoi komunikatsiinoi polityky pidpryiemstva [Actual aspects of formation of effective marketing communication policy of the enterprise]. Scientific Bullentin of Uzhhorod National University. International economic relations and the world economy (electronic journal), vol. 18. Retrieved from:http://www.visnyk-econom.uzhnu.uz.ua/archive/18_2_2018ua/8.pdf

4. Yurchenko A.I. (2020) Ekonomichna sutnist ta sklad vytrat na zbut [Current aspects of foemation of effective marketing enterprise communication policy]. Development of the system of accounting, analysis and audit in Ukraine (electronic journal), vol. 1(35). Retrieved from: http://194.44.12.92:8080/jspui/bitstream/123456789/4887/1/1\%20 \%2835\%29.pdf 